\title{
THE ISLAMIC CULTURE OF "WETU TELU ISLAM" AFFECTING SOCIAL RELIGION IN LOMBOK
}

\author{
Muliadi and Didin Komarudin \\ Ushuluddin Faculty of Sunan Gunung Djati \\ State Islamic University Bandung \\ Email: muliadi1@uinsgd.ac.id
}

\begin{abstract}
This writing is motivated by a very abundant religious culture in Indonesia, including the phenomenon found in Lombok, West Nusa Tenggara which is famous for "Wetu Telu Islam". It contains the religious system filled with ceremonies and rituals which are accompanied by special symbols that have certain meanings. The method used in this paper is historical descriptive, by systematically explaining the history of the people of Lombok, the cultural patterns of "Wetu Telu Islam", including its historical figures, doctrine, development, and existence. Then the writer uses structural semiology in analyzing the meaning of symbol elements found in the religious rituals of "Wetu Telu Islam" in Lombok. "Wetu Telu Islam" according to the people of Lombok is a very perfect Islam as it is built from two solid dimensions, namely dzohir and ihsan. For that reason, "Wetu Telu Islam" for them is the teachings of Sufism which emphasize the spirit, and soul. It is the spirit of holistic Islamic teachings, namely: shari'a, thoriqot, haqiqot, and ma'rifat. Everything is building up, mutually reinforcing, and inseparable.
\end{abstract}

Tulisan ini bermuara dari budaya agama yang sangat berlimpah di Indonesia, termasuk fenomena yang ditemukan di Lombok, Nusa Tenggara Barat yang terkenal dengan "Islam Wetu Telu". Sistem keagamaan yang terkandung di dalamnya sarat upacara dan ritual yang disertai simbol-simbol khusus bermakna tertentu. Metode yang digunakan dalam makalah ini adalah deskriptif historis, yaitu secara sistematis menjelaskan sejarah masyarakat Lombok, pola-pola 
budaya "Islam Wetu Telu", termasuk tokoh sejarah, doktrin, perkembangan dan keberadaannya. Kemudian penulis menggunakan semiologi struktural dalam menganalisis makna elemen simbol yang ditemukan dalam ritual keagamaan "Islam Wetu Telu"di Lombok. "Islam Wetu Telu" menurut masyarakat Lombok adalah Islam yang sangat sempurna karena dibangun dari dua dimensi yang kuat, yaitu dzohir dan ihsan. Karena itu, "Islam Wetu Telu" bagi mereka adalah ajaran tasawuf yang menekankan hati dan jiwa. Ini adalah semangat ajaran Islam holistik, yaitu: syariah, thoriqot, haqiqot, dan ma'rifat. Semuanya membangun, saling menguatkan, dan tak terpisahkan.

Keywords: Islamic culture; social religion; Wetu Telu Islam.

\section{Introduction}

Culture and religion have a very close relationship. In anthropology, the discussions about religion are rarely overlooked as part of the main topic. This relationship can be seen in the expression "religion reflects culture" and vice versa, "culture reflects religion". The form of religion is part of the culture in the view of several figures of anthropology and sociology. One of these figures is Malinowski who stated that the elements of culture, in general, are seven, namely: language, technological systems, livelihood systems, social organizations, knowledge systems, religion, and the arts (in Sulaeman, 1995). The father of Islamic sociology Ibn Khaldun stated that things that are included in culture are the system of kingdom or government, power, livelihood system, craft or industry, and science. He added forms in culture, namely: dynasty, religion, urban or rural society, values or morals, and all phenomena that occur as well as the hopes and ideals of society for the future. All these cultural forms are explained based on the law of causality (Kholdun, 1918). Thus, almost all elements in human life individually and socially are part of cultural studies, including religious and language as mentioned above. In the study of religious culture, some of the elements it are the focus of attention, namely: religious beliefs, human attitudes toward the occult, as well as religious rites and ceremonies. Koentjaraningrat as an anthropologist in Indonesia added that five religious components separately have their roles, however, they have close interrelationships with others. The components are religious emotion; belief system; system of rites and ceremonies; rite and ceremony equipment; and religion or people (Keontjaraningrat, 1987). 
Language in general is an object that is very concerned in cultural studies because language is the main difference or the most striking aspect between cultures found in animals and humans (Linton, 1984). Language in culture has a very broad scope, including language in the form of symbols.

A religious anthropologist, Clifford Geertz mentions that diversity is part of the cultural system. Religion is a guideline in interpreting human actions. $\mathrm{He}$ also said that religion is a system of symbols. These religious symbols will be easily understood in realistic applications. Geertz sees the system of religious symbols can be elaborated or interpreted in various ways. Most religions interpret these religious symbols through rituals and ceremonies (Tohopi, 2012). In this way, the world as imagined and as experienced is combined through symbols. These symbols have varied and speculative meanings and refer to a sign that is agreed upon and conventionally formed together by the community or culture that is living in it. As a social product, symbols are not only meaningful collectively, but can be more meaningful and pervasive in person. Symbols are the embodiment of various thoughts or ideas, attitudes, decisions, longings, and beliefs (in Sutiyono, 2010).

By resting on the theoretical foundation above, culture, religion, and language (symbol) are elements that are interrelated and form a "conclusion" that is full of meaning. It can be easily found on social societies in Indonesia, including in West Nusa Tenggara on the island of Lombok. The island is located between several islands, namely the islands of Bali, Java, and Sumbawa. The indigenous people who inhabit this island are known as the Sasak tribe. One of the cultural-religious phenomena which are full of religious and very popular meanings found in this society is Wetu Telu (Rasmianto, 2009).

Many assumptions are developing around Wetu Telu. Among these assumptions, namely: 1) a belief in spirits residing in dead objects or certain objects that have power but are subject to God's power; 2) it is a description of three basic principles that exist in life, such as past, present, and future; 3) distribution related to geographic territory, namely: there are mountains, land, and beaches; 4) division related to human life, namely: born, develop, then die; 5) while it is related to the implementation of formal worship, the prayer is performed three times and fasting is only performed at the beginning, middle and end of the month; 6) it is a form of belief that is influenced by Animism, Dynamism, and Hinduism; 7) in the political sphere, it is a picture of three structures in society that are always related, namely: custom, religion, and government; 8) Wetu Telu is the acculturation of Islamic teachings and the 
rest of the old beliefs of Animism, Dynamism, and some beliefs of Hinduism; 9) life consists of three elements, namely water, wind and land. These three elements also become the main basis of all living things that exist in the face of the earth so that they can grow, live, and breed well (Sutiyono, 2010).

Some of the assumptions and understandings above are different from the understanding found (antithesis) through interviews with several figures in the village of Pengaduk, Pringgasela District, East Lombok Regency, West Nusa Tenggara (First interview conducted on November 25, 2018). When connected with prayer, according to them, Wetu Telu is a subject, while Wetu Lima is an object. As a subject, it is the one who works, while Wetu Lima is the object that is done. The term Wetu Telu does not refer to prayer or prayer times, but an understanding originating from the Science of Sense. It starts from "insight" and is expressed in the form of qolbi, qouli, and fi ' li (ate-angen, ongkat pemuni, then heart-feeling, speech, and behavior) then incarnate in the form of a culture that is popular with the term Wetu Telu.

When readings or beliefs are wrapped up in a culture, often people are trapped in the outer layer, language, or symbol without further digging the substantial meaning stored behind it. In fact, according to (Barthes, 1977, 1988) the sign (semiology) is not limited to linguistics but includes all sign systems, whatever the substance and boundaries. Image, gestures, attitudes, musical sounds, objects, and associations are complex of all these that makeup content, rituals, conventions, or public entertainment. This constitution, if not a language, is at least systems of significance. These systems certainly refer to an idealistic concept.

Furthermore, Barthes said that semiology is not only involved in human language as Saussure said. In today's social life Barthes found a very broad system of signs outside the language. Every semiology system has a linguistic mixture. Between the sign system (semiological object) and language is an interrelation that cannot remain alone (Barthes, 1967). So, from a semiological point of view, Wetu Telu is not merely a collection of symbols in the form of tradition (in the form of a party (begawe) or others, but refers to other more meaningful substantial.

On the other hand, the existence of political pressure in the past, namely the conquest carried out by the Balinese kingdom/period, had an impact on the freedom of the Islamic ummah in Lombok. The phenomenon of the burning of mosques carried out by Balinese royal soldiers caused the Muslims of Lombok, in general, to pray in secret and highly dependent on 
security conditions. Such condition also has an impact on the reconciliation of prayers and sometimes at certain times only show the execution of three prayers, namely ashar, isya, and dawn. This condition, as if revealed a part of shari'a and hid some of the others (completing prayers imperfectly/only three times/Wetu Telu).

Sometimes it involves five times praying, namely: Asr, Maghrib, and Isha' on Thursday, and Subuh, and Zduhur on Friday. The following week was the same, working on five prayers, but not every day. This condition occurred because they were under the pressure of Dutch political power and the kingdom of Bali. This pattern of worship continued even though the occupation of the kingdom of Bali, Dutch and Japanese colonization was over.

\section{History of the Lombok Community}

Lombok Island is a third of the area of Sumbawa Island. However, the population of West Nusa Tenggara, which numbered more than three million, two-thirds live on the island of Lombok. This happens because the island of Lombok is more fertile than Sumbawa Island. Lombok Island residents are Sasak people, most of which embraced Islam.

Lombok and Sasak are two names that cannot be separated. Lombok comes from the Sasak language; "Lombo" means "straight". Sasak comes from "sak-sak" which means "boat with a joke" which is read lombo in the Sasak dialect, then, the word sak-sak is also read sa 'sa ' if it is viewed in terms of meaningful language "only". Meanwhile, when viewed in terms, this expression shows the meaning of an activity oriented to a single goal. In a religious context, the word emphasizes one goal, namely God. In the process of carrying out all activities, human beings in their lives must have understanding and sincerity, that is, everything that is related to the person must be based on lillahi ta 'ala (everything from, by, and for Allah).

Many people misunderstand. Lombok is interpreted as "chili" so that there is a meaning of Lombok island as a "spicy island". Even though chili in Sasak language is "sebia" (read "sebie"). The name Lombok in various oral and written stories in the lontar takepan is one of the names of Lombok Island. Another name that is often referred to is the island "Meneng" which means "quiet" or "clear". Some say "Gumi Sasak", some say "Gumi (earth) Selaparang", according to the name of one of the kingdoms that were famous in Lombok in ancient times, namely the kingdom of Selaparang (Interview with Papuk Diana, May 7, 2019)

el Harakah Jurnal Budaya Islam Vol. 22 No. 1 Tahun 2020 
The island of Lombok since the days of the Majapahit kingdom was famous. This is evidenced by the mention in the Negarakertagama book written by Empu Prapanca. Negarakertagama is also found in Lombok. The legend of the Sasak people tells that the Old Mataram kingdom in Central Java was led by a female king named Pramudawardhani who married Rakai Pikatan. It is said that the Empress was a government expert, while the husband was an expert on warfare. His power to the west reaches Sumatra, to the east to Flores Island. It was then that many Mataram people went sailing eastward through the Java Sea using junk boats.

Their destination for sailing is unknown. Is it to expand power or avoid heavy work, because at that time the Borobudur Temple, Prambanan Temple, and Kalasan Temple were being built by the king. So they sailed straight east and landed in a port. The port was named Lomboq (straight), to commemorate a long journey. They are straight east. Furthermore, Lombok is now not only the name of the port where the boat landed but also the name of the island of Lomboq which later turned into Lombok. They sailed using a junk boat called "sak-sak", and they were called the Sak-Sak, meaning people who came by boat. Then, they blend in with the natives. At that time, on the island of Lombok there was a kingdom called the Kedarao kingdom.

They then founded the kingdom of Lombok which is based in Labuhan Lombok (now). The Kingdom of Lombok became large, developed in five centuries, until it was known throughout the archipelago, as a port visited by traders from Tuban, Gresik, Makassar, Banjarmasin, Ternate, Tidore, even Malacca. When you come to Lombok, the Malacca buys rice, tarum and sepang wood (Interview with Papuk Diana, May 7, 2019)

The kingdom of Lombok was later defeated by the Majapahit kingdom. The king and his empress ran to the mountains and established a new kingdom which was named Watuparang later known as the Selaparang kingdom. When the name Lomboq changed to Lombok, and the name Sak-Sak changed to Sasak it was not known for certain. What is clear is that now the island is famous for the name Lombok Island and its tribe is known as the Sasak tribe. The name Selaparang has been enshrined as the name of a protocol road and the name of the airport in Mataram, the capital of the province of West Nusa Tenggara (Interview with Papuk Diana, May 7, 2019)

Lombok Island is an island in the Lesser Sunda Islands or Nusa Tenggara which is separated by the Lombok Strait from Bali in the western part and the Alas Strait to the east of Sumbawa. The island is more or less round in shape 
with a kind of "tail" on the southwest side that is approximately $70 \mathrm{~km}$ long. The area of the island reaches 5,435 km (Interview with Papuk Diana, May 7 , 2019), placing it at number 108 from the list of islands based on its size in the world. The main city on this island is the city of Mataram.

Besides Indonesian as the national language, the inhabitants of the island of Lombok (especially the Sasak tribe), Sasak language is used as the main language in everyday conversation. Throughout Lombok, the Sasak language can be found in four different dialects, namely the Lombok dialect north, center, northeast, and southeast. In addition to the large number of Balinese tribes who reside in Lombok, in some places especially in West Lombok and the Municipality of Mataram, Balinese is used as the language of everyday conversation.

Most of the inhabitants of the island of Lombok, especially the Sasak tribe, adhere to Islam. The second largest religion is Hinduism, embraced by residents of Balinese descent, which account for around $15 \%$ of the population. Christians, Buddhists, and other religions can also be found, and are mainly embraced by migrants from various ethnic groups. The largest religious organization in Lombok is Nahdlatul Wathan (NW). This organization also established many Islamic education institutions with various levels from the lowest level to tertiary institutions.

In Cakranegara (formerly called the kingdom of Cakranegara), an ancient lontar manuscript was discovered by the Dutch Expedition (KNIL) taken to the Netherlands. It was actually in the Selaparang Kingdom (now around Pringgabaya, East Lombok). During the war between Bali and Lombok, the Selaparang kingdom had been defeated because it was attacked suddenly, and finally all the property belonging to the Selaparang kingdom was seized by Balinese troops. The remains which were not carried away were then burned. These include Raja Selaparang's gold crown (Pemban Selaparang) and the lontar of Kertagama State which are being studied by the Selaparang royal sons and officers (Interview with Papuk Diana, May 7, 2019).

The history of the Sasak people is still not arranged to reach the appropriate level of local content in recognizing the history of the region. Some of the existing documents are still in the form of inventories and have not yet arrived at a complete and comprehensive level of preparation (Ansori, 2005).

The native inhabitants of the island of Lombok are called the Sasak tribe. The name Sasak in one version said it was taken from an incident when someone who wanted to find a place of residence from Java to Lombok used 
sasak which means raft. This version was then used as an argument that the ancestors of the Sasak people came from Java. It is said that the Sasak word is taken from the ancient Javanese language, namely from the word "legitimate" which means "go away" and "saka" which means "origin or ancestor". So, etymologically, the Sasak word means people who go from their hometown by using a raft as their vehicle, namely going from the island of Java to the island of Lombok and settling there. This story is reinforced by the many Javanese scripts called jejawen used in various Sasak literature and lontar (Suwondo, 1978).

If this word (Sasak) is analyzed in terms of language, we can also find this word among Sundanese. The word sasak in Sundanese means "crossing bridge". The character of a straight crossing bridge has similarities with the word lombok, which in Sasak language means straight. It could be that the absorption of the name of the island of Lombok was taken from this Sundanese language because the power factor of the Sundanese kingdom in ancient times was so extensive known as the Great Sunda and the Small Sundanese.

While in terms of understanding, this expression (sa'-sa') shows the meaning of something that shows on one activity or at one goal and does not turn to another (just one). In a religious context, the word emphasizes one purpose, God. In the process of carrying out all activities, the word also teaches that humans in their lives must have understanding and sincerity, that is, everything related to the person must be based on the concept of lillahi ta'ala (all from, by, and for Allah).

\section{Cultural Patterns of Islamic Wetu Telu and Wetu Lima}

Lately, various studies have found that there are two variants of Islam in Lombok, namely Islam, Wetu Lima, and Islam Wetu Telu. These two terms are like binary opposition. When mentioned in Wetu Lima Islam, it will signify that there is Islam in another form. This kind of polarization can be found almost in various regions in Indonesia, even the world. On the island of Java, for example, there is Islam and Islamic Abangan, which was initiated by Cliffod Gerth. In the island of Lombok, it also found a similar pattern, namely Islam of Wetu Lima and Wetu Telu. Hasty conclusions are then present in the minds of the general public, that Islam in its other forms is Islam that comes out of the main path, imperfect Islam, and various other oblique images (Interview with Papuk Diana, May 7, 2019) . 
The manifestation of the attitude of obedience and bigotry of society, including the Sasak people of Lombok, can be seen in carrying out the Islamic Shari'ah followed by consistency in carrying out the five pillars of Islam (arkanul Islam). They are saying two kalimah syahadah, praying five times a day, fasting in the month of Ramadan, performing zakat, and performing the Hajj. The five bases are strengthened by the six points of belief (arkanul iman), namely belief or belief in God (tawhid), belief in angels, belief in the holy books of the Qur'an and the scriptures revealed to the previous prophets, confidence in the Prophet, the belief in the end of the Hereafter, and believe in the provisions and destiny (qodho and qodar) of Allah.

By fulfilling the five pillars of Islam and being followed by six convictions that strengthen them, the Islamic community in general, especially the Sasak Lombok people in particular are said to carry out the Islamic Shari'ah completely or perfectly. For the Sasak people, the level of Islam in a person will be seen from his/her consistency in carrying out the five pillars. Those who consistently carry out the five pillars that form the basis of Islam are the ones who are called the Wetu Lima Islam (Budiawati, 2000).

Etymologically "Wetu Lima" means "five times" meaning practicing the five pillars of Islam (arkanul Islam) completely and perfectly or Sunni Islam" (Adonis, 1989). This condition indicates that in the Sasak community there are some groups that do not carry out the Islamic Shari'ah as a whole or perfect. The Islamic group that does not carry out the five pillars of Islam as a whole is what is then called Islam Wetu Telu (Budiawati, 2000). While in matters of belief, both the Wetu Lima Islam and Wetu Telu Islam both believed that Allah was one and the Prophet Muhammad was the messenger of Allah. In principle, the two are the same, namely believing in Allah and His messenger.

The pattern of behavior or daily behavior of the Islamic community of Wetu Telu does not fully reflect the actions ordered or advocated by Islam and they are often referred to as imperfect Shari'a. In the view of Islam in the Wetu Lima, the five daily prayers are the standard to find out whether they are included in the Islam Wetu Lima or Wetu Telu. Thus, if there is a group of people or even individuals who run part of the Islamic Shari'a, then they are associated as Islam Wetu Telu (Budiawati, 2000).

In the present, these two terms have become a trend and are popular not only among academics observing the development of Islam in Lombok but also among the Sasak Islamic community in general. The typology of Islam in these two categories is like something conventional, where Wetu Telu Islam 
is a term for those who do not carry out the Islamic Shari'ah in full or even summarize it and vice versa, the Wetu Lima Islam is those or a Sasak group that runs the Sayari'at Islam in full and perfect.

The Islamic community of Wetu Lima provides an overview of what the Islamic groups of Wetu Telu summarize worship in Islam. They explained that Islam of the Wetu Telu only carried out three pillars of Islam, namely saying two times of prayer, carrying out daily prayers, and fasting. Furthermore, in the view of Wetu Lima, the followers of Islam in the Wetu Telu only pray three times a day and night, namely Subuh, Magrib, and Isha. While the midnight and Asr prayers are not fulfilled. Wetu Lima Islam also said that Islam of the Wetu Telu did not fulfill a month of fasting, but only three days, namely the first day or the fasting month, the middle, and the end of Ramadan (Budiawati, 2000). The typologies of Wetu Telu and Wetu Lima Islam are attached to each group according to their worship system, even though both of them claim to be Muslims.

\section{The Cosmological Concept of Islam Wetu Telu}

The term "Wetu Telu" comes from the word "metu" which means "appears or comes from" and "telu" means "three". This term illustrates that all living things emerge through three kinds of reproductive systems, namely giving birth (raising), such as humans and mammals, laying eggs like birds, and reproducing from seeds and fruit (mentiuk) such as grains, vegetables, fruit materials, trees, and various other plants. Water, lay eggs, and breed are representations literally from wetu or metu telu. The focus of trust Wetu is not only limited to the reproductive system, but the word also has other meanings. The Wetu Telu adherent explained, that the Wetu Telu does not only explain the three types of reproductive systems but also points to the omnipotence of God that allows living things to live and breed themselves through the reproductive mechanism system (Budiawati, 2000).

The meaning contained in the term "Wetu Telu" is very diverse. This is because Islam in the Wetu Telu on the island of Lombok does not exist in one place but many places including suburban places. Thus each adherent or community of Wetu Tlu also has a different interpretation (Ansori, 2005).

The various interpretations contained in the term Wetu Lima and Wetu Telu are caused by the existence of leaders from each community or adherents of the Wetu Telu who are referred to as stakeholders. It is these stakeholders 
who then provide a different interpretation of the Wetu Telu following the place, culture, and environment. (Syakur, 2001).

There is another opinion saying that Wetu Telu symbolizes the dependence of living beings on one another. Related to this, they divided the cosmological region into a small universe and a large universe. The big universe they call mayapada or universe consisting of the world, sun, moon, stars, and other planets. While humans and other creatures they consider to be a small universe that depends on the universe. This interdependent relationship unites the two worlds in a balance, therefore the cosmological order becomes spinning or working. This condition also shows the omnipotence of God behind him who moves or causes this interdependence (Interview with Papuk Diana, May 7, 2019).

The form of dependence between the small universe and the big universe is reflected in the need for a small universe of important resources needed for survival, such as land, water, air, and fire or the sun as a power-generating heating system. The opposite condition, where the universe depends on the small universe in terms of maintenance and preservation. Like humans as a small universe too greedy in exploiting the universe, they will destroy the equilibrium system of the universe. The balance of the natural order reflects a harmonious dependence between the macro world and the micro world (Ansori, 2005).

As a religious system, Wetu Telu Islam has the belief that every living thing goes through three stages of a series of cycles, namely being born (begotten), living (urip), and dying (mate). Ritual activities will focus on three levels of this cycle. Each stage of this cycle is followed or accompanied by a ceremony. This represents the transition and transformation of one's status to the next or subsequent status and also reflects one's obligation to the spirit world (Budiawati, 2000).

Important elements embedded in the teachings of Islam Wetu Telu according to adat leaders, namely: first, the secret that manifests in the five senses of the human body. Second, the deposit of God's examination which is manifested in Adam and Eve. Symbolically Adam represents the father or male line, while Eve represents the mother or female line. Each of them spreads four organs in the human body. Third, God's nature is a combination of five senses (originating from God) and eight organs inherited from Adam (male line) and Eve (female line). Each of God's nature can be found in every hole in the human body.

el Harakah Jurnal Budaya Islam Vol. 22 No. 1 Tahun 2020 
Stakeholder conclusions, that faith in God, Adam, and Eve was the center of belief in Wetu Telu. This idea according to them comes from Lontar Anbiya. They explained that God created Adam's body from a handful of clay and on the sixth day He blew the spirit on Adam's head, so Adam was a living being. Stakeholder explained that Eve was created from parts of Adam's body, but it was not explained which part of Adam's body was used to create Eve (Budiawati, 2000).

With the above explanation, some points related to the Islamic belief of the Wetu Telu can be drawn, namely that they have different interpretations from the groups that are not adherents of the Wetu Telu. For the groups of Wetu Telu, they symbolically believe in three types of reproductive systems, a balance between the world of macro and micro. The ceremony accompanies each stage of the transformative process in one's life, namely: birth, life, and death, and the recognition of God's omnipotence and recognition of Adam and Eve as their ancestors.

Wetu Telu is not only in the form of ideological teachings and doctrines that are vertical, but it is incarnated in culture and customs, both in social traditions in general and in the form of horizontal religious rituals. Wetu Telu in the form of culture is based on the basic principles or doctrine of ideology, in the form of honesty, sincerity, and obedience (Interview with Khidir, May 21, 2019).

Wetu Telu in the form of an understanding concept is also called laek time (ancient times), while concerning cultural traditions it is called "laek way" (ancient ways or behavior) which is also called adat (Interview with Papuk Diana, May 7, 2019). Islamic custom known as Wetu Telu is found in eight months in a year, namely: putek porridge, abang porridge, mulud, mi'roj, rowah moon, fasting, Eid (lebaran belo), Eid (lebaran pontak). That is an Islamic custom of Wetu Telu. At eight months, there is a lot of information about procedures that can guide individuals, especially Muslims. The contents of the meanings of these eight months need to be understood and practiced in life. If not practiced, then an individual is very far from something called "ideal". The things done in the eight months are harmonious, the procedures, and explanations about the foundation or basics, as well as the sources of adat and religion, all of which are closely related to human beings. While the rest is for people outside of Islam, including Balinese people (Interview with Papuk Diana, May 7, 2019). 
Some traditions and rituals can be found in Lombok society. It includes Sorong Serah or ceremony for proposing a bride. A wedding must go through the Sorong Serah ceremony (Ahyar \& Abdullah, 2019). There is an assumption in the community that there is no marriage if there is no "Sorong Serah" ceremony and if there is a marriage but does not carry out the ceremony, then the marriage is considered a disgraceful act or will get scorn from society (Zakaria, 2018). In this ceremony, the symbolic rituals are spoken by adat leaders (from women/advocates) to the bridegroom in the form of mentioning numbers (Anggraeny, 2017). The adat leader said: ajin (price) Panjak (servant) is (one), the price of Karang Jajap (general public) 10, the price of Peroaksa (official) is 33, while Menak (king) is 66 (Interview with Pak Khidir, June 21, 2019).

\section{Leaders in the History of Wetu Telu Islam}

The development of Wetu Telu Islam goes through a very long and winding history and is filled with various obstacles. The figures who have been influential in the history of the growth and development of Islam, especially Wetu Telu in Lombok, namely: The historical figures above are: 1) Songopati, 2) Sriketip Stop, 3) Syarif (Sriketip Shepherd), 4) Bulangsa (Teacher "Bulet Beams"), 5) Bangkol teacher, 6) Amaq Pahrudin (T.G.H. Ahmad Nurul Adhzim) and Ratnata (Papuk Senan), 7) Muhammad Nur, 8) T.G.H. Ahmad Nurul Adhzim, and 9) H. Azhar (Interview with Muhammad Insan Karyadi, Khairul Hadi and Mukhlis, May 18, 2019).

\section{The doctrine of the period of Wetu Telu}

All religious leaders who have been mentioned previously from Songopati up to now, namely Azhar had a very big influence on the existence and development of religiosity until now. Based on the history of the emergence of Wetu Telu, then Wetu Telu from the early figures to the present has the basic teachings of tasawuf. It has become doctrine and ideology from time to time that is attached to the Wetu Telu. The model may be different for each character, but the substance is the same, which is to lead to the "inner depth" of man who is considered to be the main "identity" that can deliver it to God.

Songopati as the first famous figure with its main teachings, namely the single form. This teaching is evidenced by the existence of a single pillar mosque or one in the hamlet of Sukatain (an area where this was the beginning of Pengakaran, now a village because of the division of the Pengaduk village). Something that remains in the area from this mosque is the former foundation. 
This mosque has one column and is surrounded by supporting pillars, where each pole has meaning. The Songopati teaching about the single form is then interpreted as the doctrine of a tarekat. The tomb of Songopati is in Sukatain (Interview with Muhammad Insan Karyadi and Khairul Hadi, May 21, 2019).

Sukatain's name itself is an identity of a religious movement, that is part of a tarekat model, because the name of this original place, as mentioned in the historical document of the reserve is "Samarkaton Village" which at that time was ruled by Demdung under the rule of Raja Lombok. The historical document stated that Suka Tain comes from the word "Shahadatain" because it was at that place that the first pillar of Islam was taught first, namely two sentences of the creed by a first Islamic religious announcer named Songo Pati originating from Java.

In the following period, with a very long period from one figure to the next, both Sriketip Mengenti, Sriketip Menggala, and Balok Bulet continued to emphasize the teachings of Islam that were colloidal, especially its tenets. Sriketip Mengenti still has a connection with the teachings of the single form of Songopati. While Sriketip Menggala originating from Arabic is a reflection of the fertility of the reserve with the teachings of Islam. This condition is evidenced by the establishment of the first Islamic mosque in this area. Then the figure of Balok Bulet and the Naqshabandiyah order which he practiced and taught reflected that mysticism teachings were the basis of the religion of the ancient revival community.

During Muhammad Nur's religious life in the form of tarekat flourished very rapidly. When viewed in terms of the historical development of the Naqsyabandiyah Order in Lombok, as described by Martin van Bruinessen (1996). Especially around Central Lombok and East Lombok, the order taught by Muhammad Nur is this tarekat. Muhammad Nur himself was one of the students of Muhammad Ali (Interview with Amaq Nur, July 2019). He is now a student and son-in-law of Muhammad Nur and a murshid teacher in a place which was once the place of establishment and preservation of the Qodiriyah Naqsyabandiyah congregation in Timbanuh (in Pringgasela sub-district, Lombok district East). He is famous for Haji Muhammad Ali, a teacher of the Naqsyabandiyah Order in Sakra (now, East Lombok). Haji Muhammad Ali himself died in the initial battle in 1891. Haji Muhammad Ali built and developed his tarekat teachings. Many people came to him, both from nobility and ordinary people asking to be pledged. The followers 
of Haji Muhammad Ali mostly came from East Lombok, including Masbagik, Kopang, Batu Kliang, and Pringgabaya.

From the interviews, the author found that Muhammad Nur in his tarekat movement remained on the same track as the predecessor religious leaders. The teachings on prayer which are famous for the term Wetu Lima, in a very soft or slow way then began to be introduced and practiced. He often said "we fight, but did not leave the prayer", even, according to the confession of his students, let alone the obligatory prayer, the sunnah prayer was very emphasized to the students or members of his congregation (Interview with Muhammad Insan Kariadi and Khaerul Hadi, May 21, 2019).

His students also often listened to his expressions, namely "we are entitled to the Shari'a". Unification or integration of nature and Shari'a is the vision and mission of Muhammad Nur and then this effort was championed by his students as his successor. This is his top priority because it is said that the majority of the ancestors of the community who refer to ancient traditions or Wetu Telu think and understand, even believe that the spiritual area is capable and will deliver humans to their God (Interview with Khidir, May 21, 2019).

The teachings of the Qodiriyah-Naqsyabandiyah (TQN) order inherited by Muhammad Nur were also continued by the student and successor, T.G.H. Ahmad Nurul Adhzim. While the naqsyabandiyah order which is practiced and developed by Balok Bulet also gives influence and is also taught by T.G.H. Ahmad Nurul Adhim. This is evidenced by several books which were read and became a guide, namely the book Bayanul alif and Bayanulloh. The naqsyabandiah is not pure, because he often goes to Java and there he gets a lot of information and books related to religion, especially about tarekat (Interview with Mr. Diana, May 7, 2019).

\section{Islamic Network of Wetu Telu}

From the description of the figures described earlier, Wetu Telu is interpreted as a doctrine of the science of mysticism, both concerning an understanding and in religious traditions. This movement can be drawn from the very downstream, namely lately to the era of the figure of Muhammad Nur.

During the generations above, namely Guru Bangkol and Balok Bulet this movement is a local archipelago, namely the island of Lombok. This could be summed up because of the involvement of the leaders in the liberation or expulsion movement of the invaders from the island of Lombok. This eviction movement led by groups adhering to the naqshabandiah order took place not

el Harakah Jurnal Budaya Islam Vol. 22 No. 1 Tahun 2020 
only in East Lombok, but also in Central Lombok and West Lombok. All of them worked together and helped each other in a very difficult effort to get rid of the Dutch colonizers, the occupation of Bali, and Japan.

The previous generation, namely Sriketip Menggala coming from Arabia allowed having links with religious movements in the area, especially those related to his religious teachings. While Sriketip Mengenti was included in the local regional movement. As explained in the history of the beginning of Wetu Telu, Songopati came from Java, then logically it can be concluded that this religious movement is trans-island, namely the island of Java-Lombok. The movement at that time was very much related to the religious movement which was pioneered by the Walisongo.

Thematically, the religious content in general which is behind religious and cultural movements at the Wetu Telu is not only local, trans-island, and national, but international. This is clear because the tasawuf movement in the form of tarekat is flourished throughout the world from the Middle Ages. While in the form of understanding and belief there was a time from Rosululloh, even before his apostolate (Suryaningsih, 2013).

\section{Existence of Wetu Telu}

The existence of the Wetu Telu until now can still be obtained in the form of religious teachings, as well as in practice in the ritual of proximity, as has been historically-chronologically described in the history. Despite its existence in the form of cultural rituals, there are still many that can be obtained and witnessed, although some of them are only found in historical documents. This condition occured because the flow of change as a result of the culture of modernization and also technological advancements that penetrate almost all the joints of Indonesian society in general, especially the Pengandangan community. Accordingly, the local traditional culture is very difficult to survive and also gets very little attention, both by adherents of culture itself or by the government.

\section{Conclusion}

The meaning contained in the Wetu Telu Islam culture influencing the social religion in Lombok, implies the doctrine of monotheism, namely all human activities must be directed only to Allah Almighty. So this is drawn from the word "lombok" meaning "straight" which refers to the Almighty. The religious-cultural patterns found in Wetu Telu are manifested in various 
customs and are full of meaning related to birth, life, and death. The example of the patterns found in Lombok about birth is Molang Malik ceremony. Concerning life, there are Sorong Serah, Mulud, and Blayar ceremonies. While the most number is related to death, as in the symbol of the culvert, the form of the grave of the corpse, Ancak, Nenelung, Mituk, Nyiwa, Empat Pulu, Nyatus, Nyiwu, Nyenyantekin. In addition to the aforementioned ones, namely: Begawe Ceremony, Mal-Mal Mall, Begamelan Blek, Makon, Sesimbing, Wetu Telu Day, Date Determination Method of Muharrom, and Tuak Recitation.

Wetu Telu is often understood as an imperfect Islam, because it reduces all teachings or worship in Islam to three, such as the meaning of the word "time" which means "time three". Allegations directed at followers of Islam Wetu Telu as imperfect Islam, for example, praying only three times, understanding dynamism and animism, understanding the spirits of the ancestors, as well as understanding related to the other three things. The meaning is different from the Wetu Telu understanding found in Lombok. The time for the Pengluuf community is almost entirely related to the understanding of Sufism either related to ideology or manifested in customary traditions in general, especially those related to religious traditions. For the people of Lombok who believe in Wetu Telu, it is a very perfect Islam because it is built from two solid dimensions, namely dzohir and inner or Islamic, faith, and ihsan. Wetu Telu for them is Sufistic teachings or Sufism and is attached to the heart and feelings. When it is related to dzohir, Wetu Telu is words and deeds or sharia. It manifested in the phenomenon of society as a way of behaving, and a way of speaking or communicating. Wetu Telu is that if left, then someone is in the status of "very heavy disbelief", while, "Wetu Lima" is when left, then someone is in the status of "lighter disbelief".

\section{Reference}

Adonis, F. T. 1989. Suku terasing Sasak di Bayan, daerah Propinsi Nusa Tenggara Barat. Departemen Pendidikan dan Kebudayaan, Direktorat Jenderal Kebudayaan, Direktorat Sejarah dan Nilai Tradisional, Proyek Inventarisasi dan Pembinaan Nilai-Nilai Budaya

Ahyar, A., \& Abdullah, S. 2019. Sorong Serah Aji Krama tradition of Lombok Sasak marriage to revive Islamic culture. El Harakah (Terakreditasi), 21(2), 255-269.

el Harakah Jurnal Budaya Islam Vol. 22 No. 1 Tahun 2020 
Anggraeny, B. D. 2017. Keabsahan perkawinan hukum adat lombok (merarik) ditinjau dari perspektif undang-undang nomor 1 tahun 1974 tentang perkawinan dan hukum islam (studi di kabupaten lombok tengah). De Jure: Jurnal Hukum dan Syar'iah, 9(1), 43-52.

Ansori, Z. 2005. Islam Wetu Telu Dalam Pembentukan Masyarakat Sasak, Pascasarjana. Yogyakarta: Universitas Gadjah Mada.

Barthes, R. 1988. The Semiotic Challenge. New York: Hill and Any.

Barthes, R. 1977. Image, Music, Text. London: Fontana Press.

Barthes, R. 1967. Elements of Semiology. New York: Hill and Wang.

Bruinessen, M van. 1996. Tarekat Naqsyabandiyah Di Indonesia (Survei Historis, Geografis, dan Sosiologis). Bandung: Mizan.

Budiwanti, E. 2000. Islam Sasak: Wetu Telu Versus Waktu Lima. Yogyakarta: LkiS.

Kholdun, I. 1918. Muqoddimah al-Allamah Ibnu kholdun. Beirut: Dar al-Fikr.

Linton, R. 1984. The Study of Man (Antropologi: Suatu Penyelidikan Tentang Manusia), Bandung: Jemmars.

Rasmianto, R. 2009. Interrelasi Kiai, Penghulu dan Pemangku Adat dalam Tradisi Islam Wetu Telu di Lombok. El Harakah, 11(2), 138-154.

Sulaeman, M. M. 1995. Ilmu Budaya Dasar: Suatu Pengantar. Bandung: Eresco.

Suryaningsih, I. 2013. al-Haqiqoh al-Muwafaqoh li al-syari'ah: al-Tasholuh Baina al-Tasowwuf wa alSyari'ah Binusantaro fi al-Qorni 16 al-Miladi. Studia Islamika, 20(1), 99-100.

Sutiyono. 2010. Benturan Budaya Islam: Puritan dan Sinkretis. Jakarta: Kompas.

Syakur, A. A. 2001. Islam dan Kebudayaan Sasak ( Studi tentang Integrasi NilaiNilai Islam dan Kebudayaan). Doctoral Dissertation. Postgraduate Program IAIN Sunan Kalijaga Yogyakarta.

Tohopi, R. 2012. Tradisi Perayaan Isra'Mi'raj dalam Budaya Islam Lokal Masyarakat Gorontalo. El Harakah (Terakreditasi), 14(1), 135-155. 
Zakaria, L. A. 2018. Tradisi Sorong Serah Aji Krame: Upaya Memperkuat Hubungan Keluarga Suku Sasak. De Jure: Jurnal Hukum dan Syar'iah, 10(2), 81-88.

el Harakah Jurnal Budaya Islam Vol. 22 No. 1 Tahun 2020 
